$\xi^{2}=-1$

\title{
A Gondwana pre-break up related magmatism in Bafoussam area, west Cameroon: source characteristics and ${ }^{40} \mathrm{Ar} /{ }^{39} \mathrm{Ar}$ geochronology
}

\author{
Gus Djibril Kouankap Nono ${ }^{1}$, Pierre Wotchoko ${ }^{1}$, Evine Laure Tanko Njiosseu ${ }^{2}$, Sylvestre Ganno $^{3}$, Joelle Flore \\ Tene Djoukam ${ }^{3}$, Yannick Seplong ${ }^{3}$, David Guimolaire Nkouathio \\ ${ }^{1}$ Department of Geology, Higher Teacher Training College, University of Bamenda, P.O.Box 39 Bambili; Bamenda, Cameroon \\ ${ }^{2}$ Department of Earth Sciences, Faculty of Science, University of Dschang, P.O.Box 67 Dschang, Cameroon \\ ${ }^{3}$ Department of Earth Sciences, Faculty of Science, University of Yaoundé I, P.O.Box 3412 MESSA-Yaoundé, Cameroon \\ ${ }^{4}$ Department of Geology and Environmental Science, University of Buea, P.O.Box 63 Buea, Cameroon \\ *Corresponding author E-mail: kouankap@yahoo.fr
}

\begin{abstract}
The Gondwana pre-break up related formations in Bafoussam area are transitional calc-alkaline doleritic dykes exhibiting high Alumina and low Ti-Mg contents. Their REE compositions are similar to those of E-MORB $(\mathrm{Nd} / \mathrm{Nb} \approx 1, \mathrm{Zr} / \mathrm{Nb} \leq 20)$. A high partial melting of about $20 \%$ of Garnet peridotites source having primitive mantle composition, is inferred to the studied rocks. They are slightly evolved $50<\mathrm{Mg} \#<54$, and its clinopyroxenes are augite of high temperature $\left(600^{\circ} \mathrm{C}-1100^{\circ} \mathrm{C}\right)$. The studied dykes were emplaced in a within-plate tectonic setting and yield a ${ }^{40} \mathrm{Ar}-{ }^{39} \mathrm{Ar}$ plateau ages of $229 \pm 7 \mathrm{Ma}$. These ages are slightly different from those of dolerites from the ObanObudu massif (Nigeria), from the basaltic dyke of the Cameroon Volcanic Line and from the Karoo-Ferrar mafic magmatism, all interpreted as magmatism that preceded the break-up of Gondwana. The emplacement age of 229 $\pm 7 \mathrm{Ma}$ of dolerites from Bafoussam area relates them to the very early stage of Gondwana pre-break up magmatism in central Africa.
\end{abstract}

Keywords: ${ }^{40} \mathrm{Ar}-{ }^{39} \mathrm{Ar}$ Dating; Dolerites; Gondwana Break-Up; Primitive Mantle.

\section{Introduction}

In Cameroon, the basement formations are made up of Archean to Paleo-Proterozoic rocks related to the Congo Craton and of Neoprotorozoic rocks related to Pan-African orogeny; this basement is overlain in some places by tertiary to recent volcanic rocks or by sedimentary formations (Fig. 1A). Mafic doleritic dykes have been reported at the northern edge of the Congo craton in the Southeasthern part of Cameroon (Vicat et al., 1997), these intrusions of about $1 \mathrm{Ga}$ display continental tholeitic composition generated from spinel lherzolite source and are related to a pre-Panafrican Orogeny extensional phase in the area. Doleretic dykes have been reported by Vicat et al., (2001) in the Adamawa Plateau, within the Northern Domain of the Pan African Fold Belt in Cameroon. These authors related the doleritic dykes from Adamawa plateau to a magmatic activity anterior to the Cenozoic alkaline volcanism of the Cameroon Line. The doleritic dykes of Adamawa have the chemical composition of continental tholeiite and interpreted as an early stage of continental break-up indicating a lithospheric thinning. Tchouankoue et al., 2012 and 2014 reported post Pan-African $\left({ }^{40} \mathrm{Ar}^{39} \mathrm{Ar}\right.$ ages of $421.3 \pm 3.5 \mathrm{Ma}$, $404.22 \pm$ 3.51 Ma and $192.10 \pm 7.45 \mathrm{Ma}$ ) basaltic dyke swarms in the sourthern continental part of the Cameroon Volcanic Line, they concluded that these basaltic dykes could be related to the opening of the South Atlantic Ocean and less likely to the initial stages of the building up of the Cameroon Line. The mafic dykes of Lake Nyos studied by Aka et al., (2018) are alkaline and sub alkaline, they yield K-Ar ages of $231.1 \pm 4.8 \mathrm{Ma}$ and $224.8 \pm 4.7 \mathrm{Ma}$ respectively. The authors correlate it with the initiation of west Gondwana fragmentation to form the Atlantic Ocean.

The Bafoussam area belongs to the central domain of Pan-Africain Fold Belt in Cameroon and to the Cameroon Line (Fig. 1 A\&B). Kouankap et al., (2013) reported two distinct petrochemical types of doleritic dykes in Bafoussam area. In this paper, after recalling the main petrochemical characteristics, we present the pyroxene chemistry and the Argon-Argon geochronology of dolerites dykes in Bafoussam region. These new data will constraint their sources and will contribute to understand the geodynamic evolution of the Central Africa within the Gondwana geological setting. 


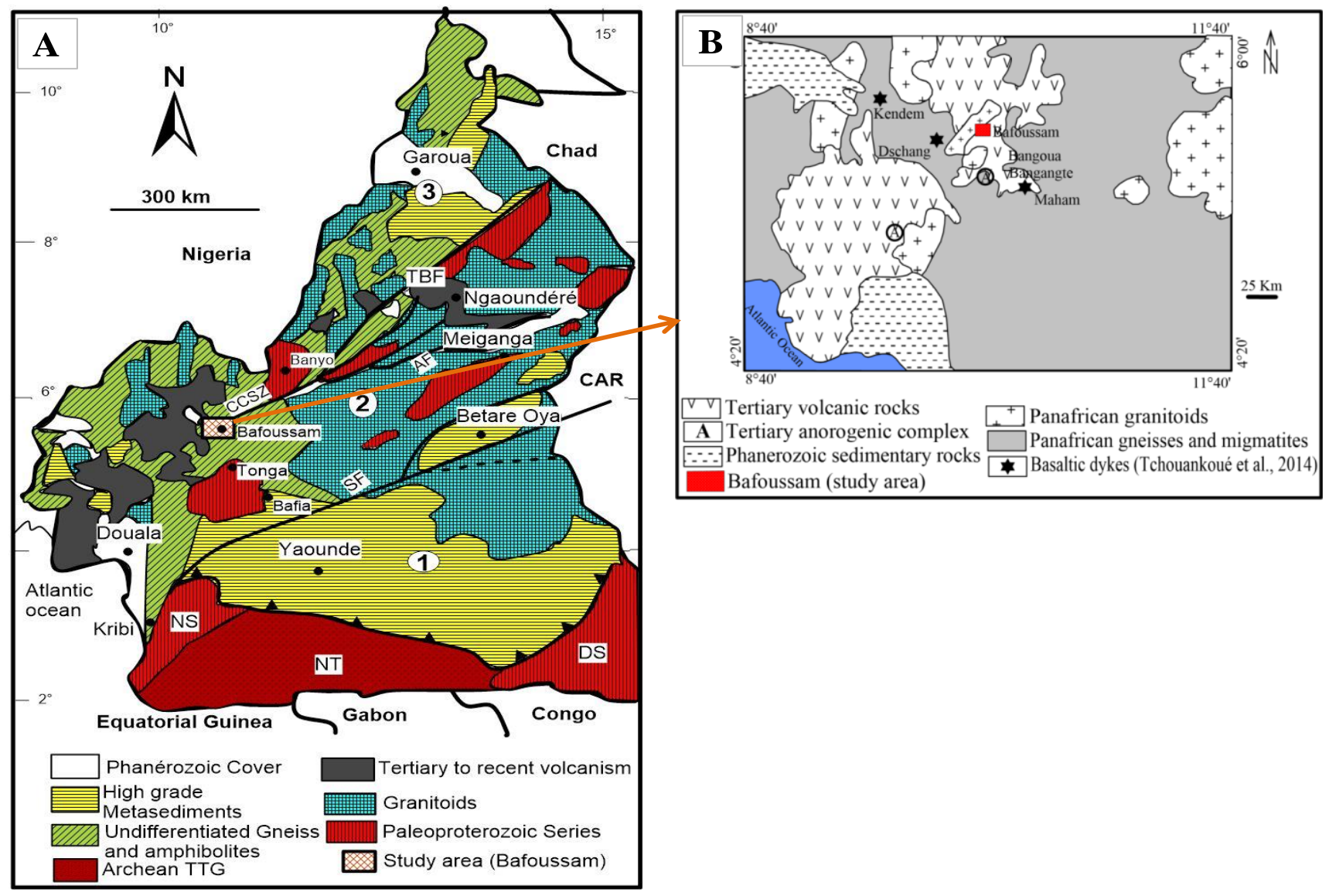

Fig. 1: Geological Maps Highlighting the Position of the Study Area. (A) Geological Map of Cameroon. Modified from Nzenti et al., 2011, (B) Geological Map of the Southern Part of Cameroon Line Modified from Tchouankoué et al., 2014

\section{Previous studies and rationale to this work}

Previous work carried out on the dolerites studied in the Bafoussam area reveals two distinct petrochemical types of dolerites: olivinebearing dolerite and calcite-bearing dolerite (Kouankap et al., 2013). The olivine-bearing dolerites are massive, compact and present a distinct doleritic texture; they are composed of plagioclase, olivine, pyroxene and opaque minerals. The matrix constitutes more than $40 \%$ of the total volume of the rock. The calcite-bearing dolerites are massive and appear greenish. The rock is composed of plagioclase, calcite, pyroxenes, amphiboles and opaque minerals. The calcite crystals $(0.5$ to $2 \mathrm{~mm})$ are sub-rounded and are associated with plagioclase and amphiboles. Amphiboles are very rare and are only observed around the rim of calcite crystals. Their crystals are fine grained; most of them constitute the matrix elements which make up about $60 \%$ of the total volume of the rock. The studied dolerites which have a basaltic composition, were less differentiated, and were different from proterozoic dolerites studied in the south of Cameroon (Vicat et al., 1998). According to the preliminary petrochemical data of dolerites from Bafoussam area, Kouankap et al., (2013) suggested that the contrast between the two types is probably due to a diverse source. This work aims at verifying this assertion, by providing their ages and more characterization of the rocks and their sources.

\section{Analytical methods}

Standard thin sections were made by Geotech lab (Canada) and the whole-rock geochemistry was performed at the commercial analytical laboratory ACME (Vancouver Canada), methods and results are presented in Kouankap et al., (2013).

The pyroxene chemistry of the elements ( $\mathrm{Si}, \mathrm{Ti}, \mathrm{Al}, \mathrm{Cr}, \mathrm{Fe}, \mathrm{Mn}, \mathrm{Mg}, \mathrm{Ni}, \mathrm{Na}, \mathrm{K}$ and $\mathrm{P}$ ) was carried out using a SX100 and SX five Camebax microprobe at the "Pierre et Marie Curie" University, Paris 6, France. The analytical conditions were as follows for clinopyroxene: 15k V and $40 \mathrm{nA}, 20 \mathrm{~s}$, except Ti (30 s). The "PAP" correction program used is defined by Pouchou and Pichoir (1991). The mineral phases were recalculated on a stoichiometric basis of oxygen and cations following the recommendations of the International Association Subcommittee on the nomenclature of minerals. The clinopyroxene phenocrysts from dolerite samples were analyzed (Table 1). The compositions have been recalculated on the basis of 4 cations and 6 oxygen atoms. $\mathrm{Fe}^{3+}$ is estimated using stoichiometric criteria according to Droop (1987).

The Ar-Ar geochronology was performed at the Department of Isotope Geochemistry, Vrije Universiteit de Boelelaan, Amsterdam, The Netherlands. The dolerites from Bafoussam were measured as groundmass separates in a 400-500 micrometer grain size interval. The ${ }^{40} \mathrm{Ar} /{ }^{39} \mathrm{Ar}$ measurements were accomplished on an MAP-215-50 mass spectrometer. Experimental methods follow those developed by Qiu and Wijbrans (2006).

\section{Results and interpretations}

\subsection{Whole rock major and trace elements}


Whole rock geochemical data were presented in Kouankap et al., 2013. The $\mathrm{SiO}_{2}$ concentrations in the samples range from 46.70 to 47.35 wt. \%; these values suggest that the studied rocks have basaltic compositions. Their $\mathrm{MgO}\left(<8\right.$ wt \%) and $\mathrm{TiO}_{2}(<2$ wt. \%) contents indicate the low-Mg and low-Ti characteristics respectively which confirm their alkaline properties. The binary diagram Alkali Index (AI) versus $\mathrm{Al}_{2} \mathrm{O}_{3}$ reveals the high alumina and calc-alkaline characteristics of Bafoussam dolerites (Fig $2 \mathrm{~A}$ ). In the $\mathrm{Nb}$ versus $\mathrm{TiO}_{2}$ binary diagram (Fig 2B), all samples plot within the transitional domain. Their Mg\# vary from 50.145 to 53.583 , indicating that the lavas of the studied rocks are from primitive mantle and have undergone little fractionation.

The values of $(\mathrm{La} / \mathrm{Yb})_{\mathrm{N}}$ vary from 3.292 to 4.921 corresponding to LREE enrichment and indicating the presence of garnet in the sourceof the rocks (Obiora and Charan 2010). The values of $(\mathrm{Tb} / \mathrm{Yb})_{\mathrm{N}}(1.471-1.626)$ and $\mathrm{Dy} / \mathrm{Yb}(1.843-2.092)$ also indicate garnetbearing peridotite sources. Their REE compositions and chondrite normalized patterns (Fig 2C) show no negative anomalies in Eu and are similar to those of E-MORB $(\mathrm{Nd} / \mathrm{Nb} \approx 1, \mathrm{Zr} / \mathrm{Nb} \leq 20)$. Plots of the rocks on the $\mathrm{Nb} / \mathrm{Y}$ versus $\mathrm{Zr} / \mathrm{Y} \log$-log diagram of Fitton et al. (1997) clearly indicate that they are related to mantle non-plume source (Fig 2D).

$\mathrm{The} \mathrm{Zr} / \mathrm{Nb}$ ratios for all rocks are less than 20 which correspond to primodial mantle characteristics (Middlemost 1975). The Nd/Nb ratios are $\approx 1$, indicating an enriched Mantle source (Fig 3).

The $\mathrm{Dy} / \mathrm{Yb}$ versus $\mathrm{La} / \mathrm{Yb}$ diagram (Fig 4) indicates that the parental magma of the studied transitional dolerites from Bafoussam area was probably formed by high degree of partial melting of about $20 \%$ of garnet peridotite at a depth relatively shallow. This high degree of partial melting $(\approx 20 \%)$ is so far the highest recorded till date from the basaltic igneous rocks in Cameroon (Fig 4) which are about $16 \%$ for transitional lavas and less than $15 \%$ for alkaline lavas occurring in a tertiary volcano-plutonic complex of Cameroon (Kuepouo et al., 2006; Fosso et al., 2005).
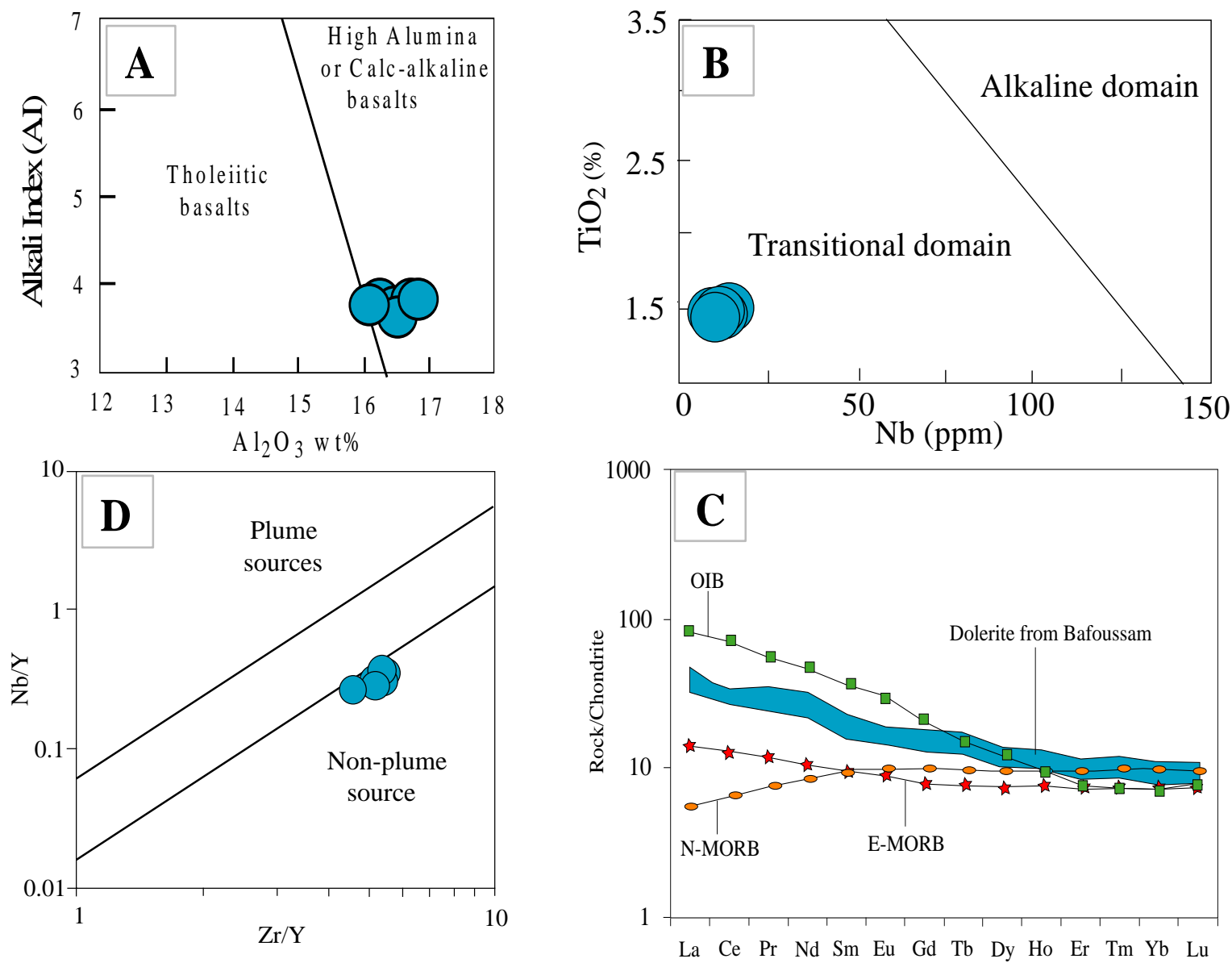

Fig. 2: Selected Diagrams of Major and Trace Elements of the Studied Dolerites from Bafoussam Area. (2A) Binary Diagram Alkali Index (AI) Versus $\mathrm{Al}_{2} \mathrm{O}_{3}$ Showing Their High Alumina Characteristics, (2B) Nb Versus Tio 2 Binary Diagram Revealing Their Transitional Aspect, (2C): Comparative Chondrite-Normalized REE Parttensof Dolerites from Bafoussam Area with OIB, N-MORB and E-MORB. (2D) Nb/Y Versus Zr/Y Log-Log Diagram of Fitton et al. (1997) for Discrimination of Mantle Plume and Non-Mantle Plume Sources. 


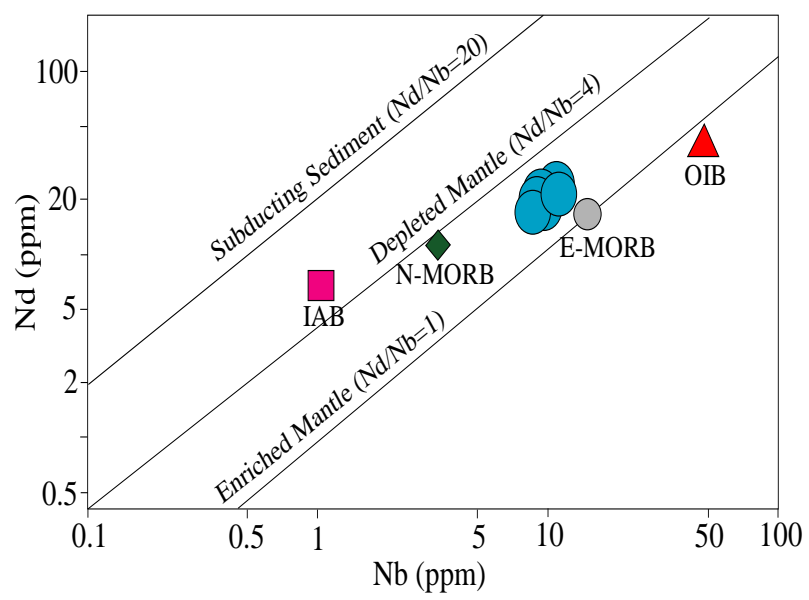

Fig. 3:Nb/Y Versus Zr/Y Log-Log Diagram of Fitton et al. (1997) for Discrimination of Mantle Plume and Non-Mantle Plume Sources.

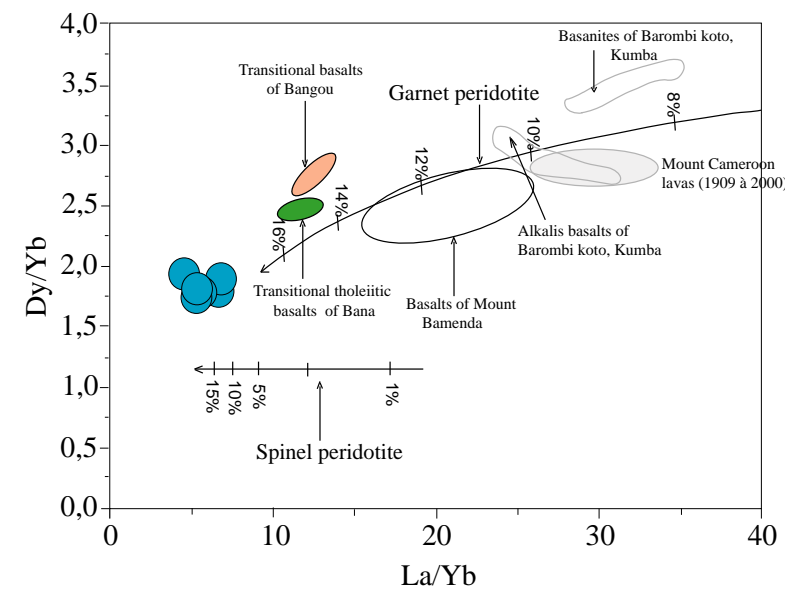

Fig. 4: $\mathrm{Dy} / \mathrm{Yb}$ Versus La/Yb Diagram for Dolerites from Bafoussam Area. Curves Are Degrees of Melting for Garnet Peridotite and Spinel Peridotite

\subsection{Mineral chemistry of pyroxenes}

(Bogaard et al., 2003).

The data of clinopyroxene phenocrysts chemistry is presented in table 1 .

The variation of their composition is illustrated in the diagram of Morimoto et al. (1988). All the analysed crystals plot within the augite domain (Fig. 5). Pyroxenes display narrow compositional variation (Wo35.83-43.41En30.10-46.31Fs12.97-31.20; Mg*=0.50-0.78). Their alumina varies from 1.29 . wt. $\%$ to 7.33 wt. $\%$. The $\mathrm{TiO}_{2}$ contents are variably low in the range of 0.32 to $2.50 \mathrm{wt} . \%$. Kushiro (1960) showed that during magmatic crystallization, the proportion of $\mathrm{Si}$ increases in the pyroxene structure whereas that of $\mathrm{Al}$ in the tetrahedral site decreases. $\mathrm{Al}^{\mathrm{IV}}>\mathrm{Al}^{\mathrm{VI}}$ is somewhat typical of pyroxene formed at high temperature.

The estimation of temperature for Bafoussam dolerites is made using pyroxene thermometry (Lindsley, 1983).Figure 6 displays the plot of pyroxene data on graphical thermometer, calibrated for a pressure of 1 atmosphere. It indicates a wide temperature range of $600^{\circ} \mathrm{C}$ to $1100^{\circ} \mathrm{C}$, based on the Lindsley (1983) graph. According to the amounts of Ti $(0.32-2.50 \%)$ and $\mathrm{Ca}(17.72-20.43 \%)$, the clinopyroxenes can be classified as titaniferous calcic clinopyroxene. The clinopyroxenes of the present work are closer to those of the Bangangte, Dschang and Manjo areas (Tchouankoué et al., 2012, 2014) with Wo49-43Ens $32-43 \mathrm{Fs}_{12-24}$ in composition, and to those of the Bana transitional tholeiites with compositions in the range of Wo47-36 $\mathrm{Ens}_{35-40} \mathrm{Fs}_{15-25}$ (Kuepouo et al., 2006), than to the representatives basaltic dykes in the Adamawa Plateau with Wo38-26Ens42-54Fs23-52 (Vicat et al., 2001). 
Table 1: Chemical Data of Pyroxene

\begin{tabular}{|c|c|c|c|c|c|c|c|c|}
\hline \multirow{2}{*}{$\begin{array}{l}\text { Sample } \\
\mathrm{SiO}_{2}\end{array}$} & \multicolumn{7}{|c|}{ Dolerites from Bafoussam } & \multirow[b]{2}{*}{49.95} \\
\hline & 48.43 & 52.02 & 50.32 & 50.68 & 49.8 & 49.43 & 51.9 & \\
\hline $\mathrm{TiO}_{2}$ & 2.5 & 1.11 & 1.53 & 1.9 & 1.07 & 1.94 & 0.74 & 1.88 \\
\hline $\mathrm{Al}_{2} \mathrm{O}_{3}$ & 7.33 & 1.64 & 3.29 & 4.41 & 2.4 & 3.54 & 1.29 & 3.46 \\
\hline $\mathrm{Cr}_{2} \mathrm{O}_{3}$ & 0.09 & 0.04 & 0 & 0.01 & 0.05 & 0 & 0.05 & 0 \\
\hline FeO & 11.24 & 11.44 & 11.03 & 10.63 & 13.84 & 10.28 & 13.11 & 11.02 \\
\hline MnO & 0.32 & 0.39 & 0.28 & 0.34 & 0.51 & 0.27 & 0.47 & 0.25 \\
\hline MgO & 11.6 & 15.05 & 13.45 & 12.29 & 11.72 & 13.23 & 14.56 & 13.18 \\
\hline $\mathrm{NiO}$ & 0 & 0 & 0 & 0 & 0 & 0 & 0 & 0 \\
\hline CaO & 18.05 & 18.18 & 20.15 & 19.32 & 19.29 & 20.43 & 17.23 & 19.87 \\
\hline $\mathrm{Na}_{2} \mathrm{O}$ & 0.33 & 0.21 & 0.33 & 0.39 & 0.32 & 0.33 & 0.21 & 0.34 \\
\hline $\mathbf{K}_{2} \mathbf{O}$ & 0.05 & 0 & 0 & 0.04 & 0.04 & 0 & 0.01 & 0.02 \\
\hline Total & 99.94 & 100.09 & 100.37 & 99.99 & 99.05 & 99.45 & 99.57 & 99.97 \\
\hline \multicolumn{9}{|c|}{ Formulae based on 6 oxygens } \\
\hline Si & 0.81 & 0.87 & 0.84 & 0.84 & 0.83 & 0.82 & 0.86 & 0.83 \\
\hline $\mathbf{T i}$ & 0.03 & 0.01 & 0.02 & 0.02 & 0.01 & 0.02 & 0.01 & 0.02 \\
\hline Al & 0.14 & 0.03 & 0.06 & 0.09 & 0.05 & 0.07 & 0.03 & 0.07 \\
\hline Cr & 0 & 0 & 0 & 0 & 0 & 0 & 0 & 0 \\
\hline$F e_{t}$ & 0.16 & 0.16 & 0.15 & 0.15 & 0.19 & 0.14 & 0.18 & 0.15 \\
\hline Mn & 0 & 0.01 & 0 & 0 & 0.01 & 0 & 0.01 & 0 \\
\hline Mg & 0.29 & 0.37 & 0.33 & 0.3 & 0.29 & 0.33 & 0.36 & 0.33 \\
\hline $\mathbf{N i}$ & 0 & 0 & 0 & 0 & 0 & 0 & 0 & 0 \\
\hline Ca & 0.32 & 0.32 & 0.36 & 0.34 & 0.34 & 0.36 & 0.31 & 0.35 \\
\hline $\mathbf{N a}$ & 0.01 & 0.01 & 0.01 & 0.01 & 0.01 & 0.01 & 0.01 & 0.01 \\
\hline \multirow[t]{2}{*}{$\mathbf{K}$} & 3.6 & 0 & 0 & 2.69 & 2.76 & 0 & 0.61 & 1.41 \\
\hline & 2.98 & 8.98 & 8.98 & 3.59 & 3.56 & 9.06 & 6.73 & 5.03 \\
\hline Si & 2.4 & 7.78 & 7.52 & 3.03 & 2.95 & 7.45 & 5.81 & 4.18 \\
\hline$A I^{\prime V}$ & 0.43 & 0.22 & 0.48 & 0.31 & 0.17 & 0.55 & 0.17 & 0.34 \\
\hline $\mathbf{T i}$ & 0.09 & 0.12 & 0.17 & 0.09 & 0.05 & 0.22 & 0.06 & 0.12 \\
\hline $\mathrm{Al}^{\mathrm{VI}}$ & 0 & 0.06 & 0.1 & 0 & 0 & 0.08 & 0 & 0 \\
\hline Cr & 0 & 0 & 0 & 0 & 0 & 0 & 0 & 0 \\
\hline$F e_{t}$ & 0.47 & 1.43 & 1.38 & 0.53 & 0.68 & 1.3 & 1.23 & 0.77 \\
\hline Mn & 0.01 & 0.05 & 0.04 & 0.02 & 0.03 & 0.03 & 0.04 & 0.02 \\
\hline Mg & 0.86 & 3.35 & 3 & 1.09 & 1.03 & 2.97 & 2.43 & 1.64 \\
\hline $\mathbf{N i}$ & 0 & 0 & 0 & 0 & 0 & 0 & 0 & 0 \\
\hline Ca & 0.96 & 2.91 & 3.23 & 1.24 & 1.22 & 3.3 & 2.07 & 1.78 \\
\hline $\mathbf{N a}$ & 0.03 & 0.06 & 0.1 & 0.04 & 0.04 & 0.1 & 0.05 & 0.06 \\
\hline & 10.74 & 0 & 0 & 9.65 & 9.83 & 0 & 4.13 & 7.08 \\
\hline$M 1+M 2$ & 16 & 16 & 16 & 16 & 16 & 16 & 16 & 16 \\
\hline $\mathrm{Fe}^{3+}$ & 0.47 & 0 & 0.14 & 0.53 & 0.68 & 0.13 & 1.23 & 0.77 \\
\hline $\mathrm{Fe}^{2+}$ & 0 & 1.43 & 1.24 & 0 & 0 & 1.17 & 0 & 0 \\
\hline FeO* & 0 & 11.44 & 9.95 & 0 & 0 & 9.27 & 0 & $\mathrm{O}$ \\
\hline $\mathrm{Fe}_{2} \mathrm{O}_{3}{ }^{\star}$ & 12.49 & 0 & 1.21 & 11.81 & 15.38 & 1.12 & 14.56 & 12.24 \\
\hline Mg/Mg+Fet & 0.65 & 0.7 & 0.68 & 0.67 & 0.6 & 0.7 & 0.66 & 0.68 \\
\hline En & 37.35 & 43.28 & 39.23 & 38 & 34.84 & 39.09 & 42.13 & 39 \\
\hline Fs & 20.89 & 19.12 & 18.52 & 19.04 & 23.94 & 17.5 & 22.05 & 18.73 \\
\hline Wo & 41.76 & 37.6 & 42.25 & 42.97 & 41.22 & 43.41 & 35.83 & 42.28 \\
\hline
\end{tabular}

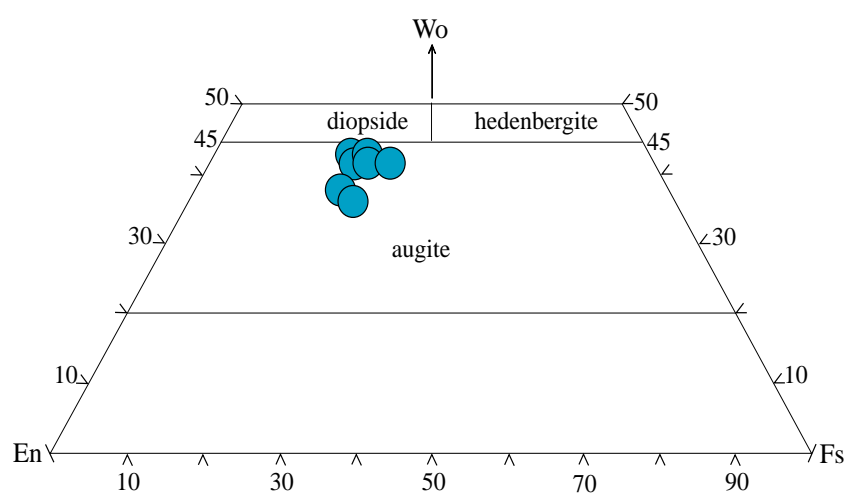

Fig. 5: Ca-Mg-Fe Diagram of Pyroxene Composition of Dolerites from Bafoussam. 


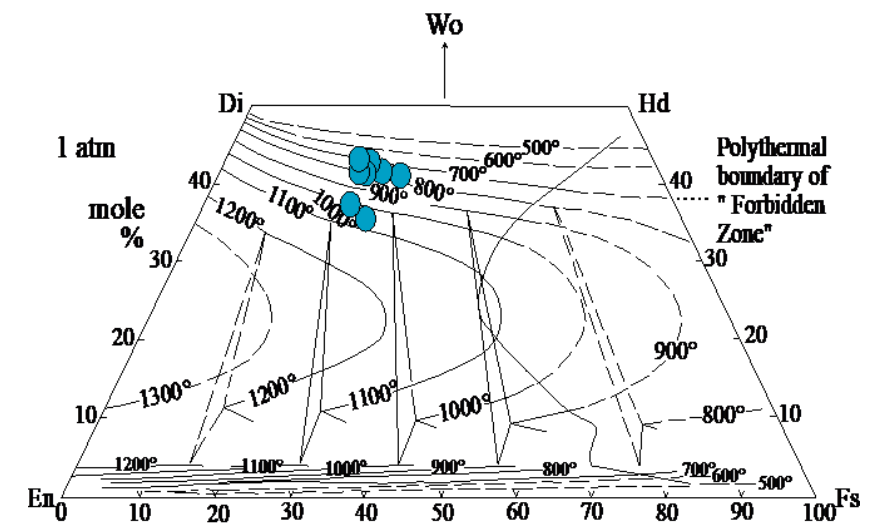

Fig. 6: Temperature Estimation of Clinopyroxene of Dolerite from Bafoussam Area.

\subsection{Geochronology, ${ }^{39} \mathrm{Ar}-{ }^{40} \mathrm{Ar}$ dating}

The summary of the Ar-Ar geochronological data of the representative samples of dolerites from Bafoussam area is presented in table 2 .

It should be noted that the gas is released by progressive crushing and not by progressive heating as is more commonly the case in ${ }^{40} \mathrm{Ar} /{ }^{39} \mathrm{Ar}$ dating experiments. The results of these stepwise-crushing experiments are presented in apparent age spectrum plots and in ${ }^{36} \mathrm{Ar} /{ }^{40} \mathrm{Ar}$ vs. ${ }^{39} \mathrm{Ar} /{ }^{40} \mathrm{Ar}$ diagrams (Fig. 10). The age spectrum is a convenient way to present the data in terms of progressive gas release (Qiu and Wijbrans, 2006). The data from dolerites crushing experiments define a homogenous line on the normal isochron diagram but showing a disparity in the inverse isochron diagram. Dolerites from Bafoussam yielded an Ar-Ar age of 229.03 $\pm 7.07 \mathrm{Ma}$ (Fig. 7), the patterns of cumulative ${ }^{39} \mathrm{Ar}$ released $\%$, show a slight variation in the age plateau

These ages are slightly different (older) from the dolerites of the Oban-Obudu massif of southeastern Nigeria which gave K-Ar plagioclase ages of $204.0 \pm 9.9 \mathrm{Ma}$ and $219.9 \pm 4.7 \mathrm{Ma}$ (Ekweme et al., 1994). The basaltic dykes from the southern continental part of the Cameroon Volcanic Line reported by Tchouankoue et al., (2014) yielded ${ }^{40} \mathrm{Ar} /{ }^{39} \mathrm{Ar}$ ages of $421.3 \pm 3.5 \mathrm{Ma}$ (Dschang), $404.22 \pm 3.51 \mathrm{Ma}$ (Maham), and 192.10 \pm 7.45 Ma (Kendem). Aka et al., (2018) obtained K-Ar ages of 231.1 $\pm 4.8 \mathrm{Ma}$ and $224.8 \pm 4.7 \mathrm{Ma}$ from alkaline and sub alkaline mafic dykes respectively in Nyos. All these ages are interpreted as a magmatism that pre-dated the west Gondwana break-up in the central Africa domain (Fig 8). Karoo (Africa), Ferrar (Antarctica) and Chon Aike (South America) mafic volcanism erupted at c. $180 \pm 4 \mathrm{Ma}\left({ }^{40} \mathrm{Ar} /{ }^{39} \mathrm{Ar}\right)$, this mafic magmatism including extensive mafic dykes is closely associated with lithospheric extension and are related to continental break-up (Teal and Kim, 2001).

In south China, Mesozoic mafic dykes (K-Ar ages of 131 - $69 \mathrm{Ma}$ ) were triggered by the reactivation of deep fault in the context of lithosphere extension (Qi et al., 2012). Based on the fact that transitional lavas are related to the extension of the lithosphere, we suggest that dolerites from Bafoussam area may represent an early stage of the maximum extension of the lithosphere reported below the Cameroon line in Cenozoic times (Kuepouo et al., 2006). This extension could be the result of the post Pan-African orogeny relaxation in Cameroon recorded in Bafoussam by the doleritic dykes emplaced during the upper Triassic period of the Mesozoic Era. The majority of the studied post Pan African dolerite dykes in Cameroon are within the Cameroon Line which is a mega structure sub-parallel to the major strike slip faults of the central domain of the pan African fold belt in Cameroon, suggesting that their emplacements were probably favoured by those regional scaled structures.

Table 2: Summary Data of Ar-Ar Dating of Dolerites from Bafoussam

\begin{tabular}{|c|c|c|c|c|c|c|c|}
\hline sample codes & AGE & 2-Sigma & MSWD & $\begin{array}{l}\%, \mathrm{n} \text { in } \\
\text { plateau }\end{array}$ & $\mathrm{K} / \mathrm{Ca}$ & 2-sigma intercept & 2-sigma \\
\hline \multirow[t]{3}{*}{$\begin{array}{l}\text { VU82-C8 } \\
\text { G14V1 }\end{array}$} & 229,03 & $\begin{array}{c} \pm 7,07 \\
\pm 3,09 \%\end{array}$ & 324,29 & $\begin{array}{c}49,45 \\
12\end{array}$ & 0,108 & $\pm 0,019 \quad 356,7326$ & $\begin{array}{c} \pm 12,9006 \\
\pm 3,62 \%\end{array}$ \\
\hline & $\begin{array}{c}\text { isochron } \\
\text { age }\end{array}$ & 2-Sigma & MSWD & 40AR/39Ar & 2-Sigma & & \\
\hline & 216,06 & $\begin{array}{c} \pm \mathbf{3 , 5 8} \\
\pm 1,65 \%\end{array}$ & 28,65 & 42,2996 & $\begin{array}{l} \pm 1,3794 \\
\pm 3,26 \%\end{array}$ & & \\
\hline
\end{tabular}



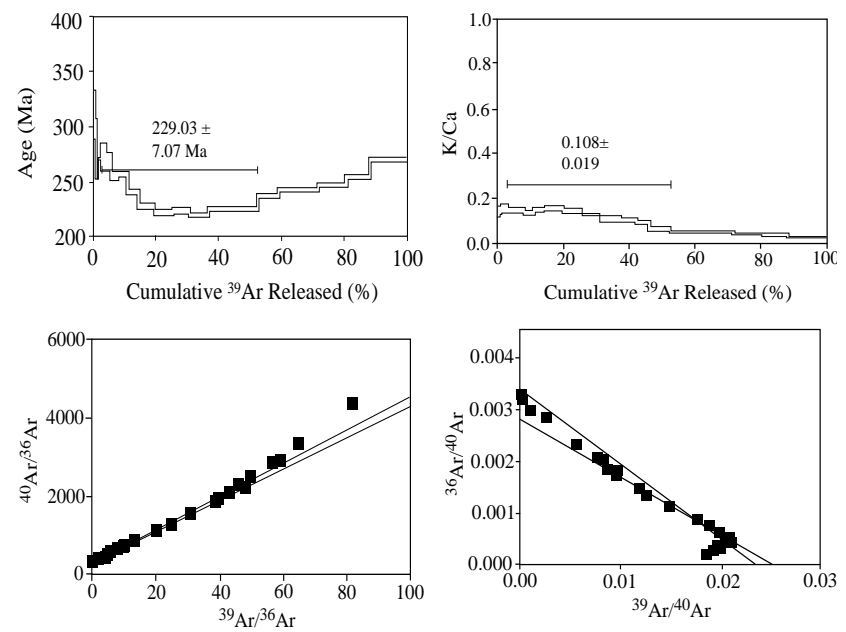

Fig. 7: Ar-Ar Ages Plateau and Isochron Plots of the Dolerites from Bafoussam Area.

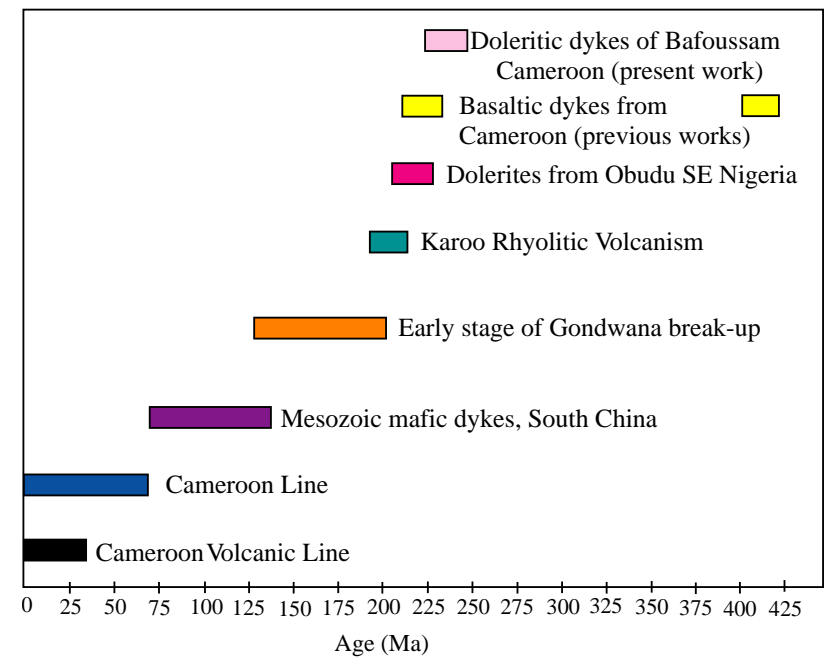

Fig. 8: Ages Summary of Some Selected Volcanic and Sub-Volcanic Activities with Regards to the Studied Dolerites.

\section{Conclusion}

The main conclusions of this paper are:

1) Dolerites from Bafoussam area are transitional calc-alkaline basalts, with high Alumina and low Mg contents. Their parental magma evolved mostly by fractional crystallization and their REE compositions are similar to those of the E-MORB.

2) The clinopyroxenes of dolerites from Bafoussam area are similar to those of transitional basaltic lavas and other basaltic dykes described in Cameroon. They yielded a wide range of temperatures from $600^{\circ} \mathrm{C}$ to $1100^{\circ} \mathrm{C}$.

3) Dolerites from Bafoussam area are relatively highly fractionated; the parental magmas were probably formed by high degree of partial melting of about $20 \%$ of garnet peridotite, which is so far the highest degree of partial melting recorded till date from the basaltic igneous rocks in Cameroon.

4) Dolerites from the Bafoussam area were emplaced in a within plate tectonic setting and yield an ${ }^{40} \mathrm{Ar}-{ }^{39} \mathrm{Ar}$ plateau age of $229 \pm 7 \mathrm{Ma}$. These ages are slightly different from the ages of dolerites of the Oban-Obudu massif of southeastern Nigeria, from the basaltic dykes of the southern continental part of the Cameroon Volcanic Line and from the Karoo and ferrar mafic magmatism, but all interpreted as intrusions preceding the break-up of Gondwana.

5) The emplacement age of $229 \pm 7 \mathrm{Ma}$ of doleritic dykes from Bafoussam area relates them to the very early stage of Gondwana prebreak up magmatism in central Africa and probably to the post Panafrican relaxation/extension phase underligned by the major strike slip fault of the central domain of Pan African Fold Belt in Cameroon to which Bafoussam area belongs.

\section{Acknowledgements}

The authors wish to thank the anonymous reviewers for the comments and suggestions that permitted to improve the manuscript. The authors acknowledge "African aura resources" the mineral exploration company, through which fund was raised to carry out standard thin sections, whole rock geochemistry and Argon-Argon dating in various commercial laboratories. Special thanks go to Professor Jan WIJBRANS of the Department of Isotope Geochemistry, Vrije Universiteit, Amsterdam, The Netherlands, for the discount granted to us on Ar-Ar dating and for his helpful collaboration. Pyroxene chemistry was done under the second author postdoctoral position scholarship at the University of Paris 6, thanks to the French cooperation. 


\section{References}

[1] Aka F., T., Hasegawa T., Nche L., A., Asaah, A. N. E., Mimba, M., E., Teitchou, I., Ngwa C., Miyabuchi, Y., Kobayashi T., Kankeu B., Yokoyama T., Tanyileke G., Ohba, T., Hell, J., V., Kusakabe M. 2018. Upper Triassic mafic dykes of Lake Nyos, Cameroon (West Africa) I: K-Ar age evidence within the context of Cameroon Line magmatism, and the tectonic significance. Journal of AficanEatrh Sciences, 141, 4959.https://doi.org/10.1016/j.jafrearsci.2018.02.001

[2] Barth, N.E., 1994. Basaltic magmatism related to the early stages of rifting along the Benue Trough: The Obudu dolerites of south-east Nigeria. Geological journal 29, (3), 269-276. https://doi.org/10.1002/gj.3350290306.

[3] Barth, N.E., Tetsumaru, I., Hisatomo, Y., 1997. K-Ar ages of intrusive rocks in the Oban-Obudu massif and their significance for the tectonic and plutonic history of southeastern Nigeria. Island arc.6, (4), 353-360. https://doi.org/10.1111/j.1440-1738.1997.tb00045.x.

[4] Caldeira, R., \&Munhà, J.M., 2002. Petrology of ultramafic nodules from Sao Tomé

[5] Island, Cameroon Volcanic Line (oceanic sector). J. Afr. Earth Sci., 34, 231-246.

[6] Droop, G.T.R., 1987. A general equation for estimating $\mathrm{Fe}^{3+}$ concentrations in ferromagnesian silicates and oxides from microprobe analyses, using stoichiometric criteria. Mineral. Mag., 51, 431 - 435.https://doi.org/10.1180/minmag.1987.051.361.10.

[7] Fitton, J.G., Saunders, A.D., Norry, M.J., Hardarson, B.S., Taylor, R.N., 1997. Thermaland chemical structure of the Iceland plume. Earth and Planetary Science Letters. 153, 197-208.https://doi.org/10.1016/S0012-821X(97)00170-2.

[8] Fosso, J., Ménard, J.J., Bardintzeff, J.M., Wandji, P., Tchoua, F.M., Bellon, H., 2005. Les laves du Mont Bangou : Une première manifestation volcanique éocène, à affinité transitionnelle, de la ligne du Cameroun. Comptes Rendus Geoscience 337, 315-325. https://doi.org/10.1016/j.crte.2004.10.014.

[9] Kouankap Nono, G.D., Wotchoko, P., Ganno, S., Ngong N.D., Nzenti, J.P., SuhCheo, E., 2013. Petrochemical Characterization of Two Distinct Types of Dolerites from Bafoussam Area, West Cameroon. International Journal of Geosciences, 2013, (4), 1131-1144. https://doi.org/10.4236/ijg.2013.48107.

[10] Kuepouo, G., Tchouankoue, J.P, Nagao, T., Sato, H., 2006. Transitional tholeiitic basalts in the Tertiary Bana volcano-plutonic complex, Cameroon Line. J. Afr. Earth Sci: 45: 318-32.https://doi.org/10.1016/j.jafrearsci.2006.03.005.

[11] Kushiro, I., 1960. Si-Al relations in clinopyroxenes from igneous rocks. Amer. J. Sci. 258, 548-554.https://doi.org/10.2475/ajs.258.8.548.

[12] Lindsley, D.H. \& Andersen, D.J., 1983. A Two-pyroxene thermometer. Proceedings of the Thirteenth Lunar and planetary Science Conference, Part 2. Journal of Geophysical Research, 88, Supplement, A887-A906.https://doi.org/10.1029/JB088iS02p0A887.

[13] Middlemost, E.A.K., 1975. The basalt clan, Earth Sci. Rev. 11, 337-364.https://doi.org/10.1016/0012-8252(75)90039-2.

[14] Milelli, L., Fourel, L., Jaupart, C., 2012. A lithospheric instability origin for the Cameroon Volcanic Line. Earth Planet Sci. Lett. 335-336:8087.https://doi.org/10.1016/j.eps1.2012.04.028

[15] Morimoto, N., Fabries, J., Ferguson, K.A., Ginzburg, I.V., Ross, M., Seifert, F.A., Zussman, J., 1988. Nomenclature of pyroxenes. Soc.Française de Minéralogie et de Cristallographie, 535-550.https://doi.org/10.1180/minmag.1988.052.367.15.

[16] Nzenti J. P., Abaga B., Suh C. E. and Nzolang C., 2011. Petrogenesis of peraluminous magmas from the Akum-Bamenda Massif, Pan-African Fold Belt, Cameroon. International Geology Review 53, 1121-1149.https://doi.org/10.1080/00206810903442402.

[17] Obiora, S.C. \& Charan, S.N., 2010. Geochemical constraints on the origin of some intrusive igneous rocks from the Lower Benue rift, Southeastern Nigeria. Journal of African Earth Sciences, 58, 1997-2010.https://doi.org/10.1016/j.jafrearsci.2010.03.002.

[18] Pouchou, J.L. \& Pichoir, F., 1991. Quantitative analysis of homogeneous or stratified micro volumes applying the model "PAP", In: Electron Probe Quantitation Heinrich K., Newbury D., pp. 31-76, Plenum Press, ISBN 0306438240, 9780306438240, New York.https://doi.org/10.1007/978-14899-2617-3_4

[19] Qi, Y., Hu, R., Liu, S., Coulson, M.I., Qi, H., Tian, J., Feng C., Wang, T., 2012. Geochemical and Sr-Nd-Pb isotopic compositions of Mesozoic mafic dikes from the Gan-Hang tectonic belt, South China: petrogenesis and geodynamic significance. International Geology Review. 54, 8, 920 939 https://doi.org/10.1080/00206814.2011.588820.

[20] Qiu, H.N. \& Wijbrans, J.R., 2006. Paleozoic ages and excess 40Ar in garnets from the Bixiling eclogite in Dabieshan, China: New insights from 40Ar/39Ar dating by stepwise crushing. Geochim. Cosmochim. Acta 70 (9), 2354-2370.https://doi.org/10.1016/j.gca.2005.11.030.

[21] Tchouankoue, J.P., SimeniWambo, N.A., KagouDongmo, A., Wörner, G., 2012. Petrology, Geochemistry, and Geodynamic Implications of Basaltic Dyke Swarms from the Southern Continental part of the Cameroon Volcanic Line, Central Africa. The Open Geology Journal, 6, (1), 7284.https://doi.org/10.2174/1874262901206010072.

[22] Tchouankoue, J.P., Simeni Wambo N.A., Kagou Dongmo, A., Xian-Hua L., 2014. ${ }^{40} \mathrm{Ar} /{ }^{39} \mathrm{Ar}$ dating of basaltic dykes swarm in Western Cameroon Evidence of late Paleozoic and Mesozoic magmatism in the corridor of the Cameroon Line. Journal of African Earth Sciences, 93, 1422.https://doi.org/10.1016/j.jafrearsci.2014.01.006.

[23] Teal, R.R. \& Kim, B.K., 2001. Age of pre-break-up Gondwana magmatism. Antarctic Science 13(2), 99-110 https://doi.org/10.1017/S0954102001000177.

[24] Vicat, J.P., Pouclet, A., Nkoumbou, C., Semé, M.A., 1997. The fissural Neoproterozoic volcanism of the lower Dja, Yokadouma (Cameroon) and Nola (RCA) Series - Geotectonic meaning. Comptes Rendu Academie des Sciences, 325, 671-677.https://doi.org/10.1016/S1251-8050(97)89109-4

[25] Vicat, J.P., Pouclet, A., Nsifa, E., 1998. Les Dolérites du Groupe du Ntem (Sud Cameroun) et des Régions Voisines (Centrafrique, Gabon, Congo, Bas Zaïre) : Caractéristiques Géochimiques et Place dans l'évolution du Craton du Congo au Protérozoïque, In: J.P. Vicat and P. Bilong, Eds., Géologie et Environnements au Cameroun, Collection GEOCAM, pp. 305-324.

[26] Vicat, J.P., Ngounouno, I., Pouclet, A., 2001. Existence de dykes doléritiques anciens à composition de tholeiites continentales au sein de la province alcaline de la Ligne du Cameroun. Implications sur le contexte géodynamique. C. R. Acad. Sci. Paris, 332 : $243-$ 9.https://doi.org/10.1016/S1251-8050(01)01526-9. 